\title{
Evaluation of the use of dry cow antibiotics in low somatic cell count cows
}

\author{
C. G. M. Scherpenzeel, ${ }^{* 1}$ I. E. M. den Uijl, ${ }^{*}$ G. van Schaik, ${ }^{*}$ R. G. M. Olde Riekerink, ${ }^{*}$ J. M. Keurentjes, ${ }^{*}$ \\ and T. J. G. M. Lam*† \\ ${ }^{*}$ GD Animal Health, PO Box 9, 7400 AA Deventer, the Netherlands \\ †Department Farm Animal Health, Utrecht University, PO Box 80151, 3508 TD Utrecht, the Netherlands
}

\begin{abstract}
The goal of dry cow therapy (DCT) is to reduce the prevalence of intramammary infections (IMI) by eliminating existing IMI at drying off and preventing new IMI from occurring during the dry period. Due to public health concerns, however, preventive use of antibiotics has become questionable. This study evaluated selective DCT in 1,657 cows with low somatic cell count (SCC) at the last milk recording before drying off in 97 Dutch dairy herds. Low SCC was defined as $<150,000$ cells $/ \mathrm{mL}$ for primiparous and $<250,000$ cells/ $\mathrm{mL}$ for multiparous cows. A split-udder design was used in which 2 quarters of each cow were treated with dry cow antibiotics and the other 2 quarters remained as untreated controls. The effect of DCT on clinical mastitis (CM), bacteriological status, SCC, and antibiotic use were determined at the quarter level using logistic regression and chi-squared tests. The incidence rate of CM was found to be 1.7 times (95\% confidence interval $=1.4-2.1$ ) higher in quarters dried off without antibiotics as compared with quarters dried off with antibiotics. Streptococcus uberis was the predominant organism causing CM in both groups. Somatic cell count at calving and $14 \mathrm{~d}$ in milk was significantly higher in quarters dried off without antibiotics $(772,000$ and 46,000 cells/mL, respectively) as compared with the quarters dried off with antibiotics $(578,000$ and 30,000 cells/mL, respectively). Quarters with an elevated SCC at drying off and quarters with a positive culture for major pathogens at drying off had a higher risk for an SCC above 200,000 cells $/ \mathrm{mL}$ at $14 \mathrm{~d}$ in milk as compared with quarters with a low SCC at drying off and quarters with a negative culture for major pathogens at drying off. For quarters that were culture-positive for major pathogens at drying off, a trend for a higher risk on CM was also found. Selective DCT, not using DCT in cows that had a low SCC at the last milk recording before drying off, significantly increased the incidence rate of CM and SCC. The decrease in antibiotic use by
\end{abstract}

Received October 30, 2013.

Accepted March 4, 2014.

${ }^{1}$ Corresponding author: c.scherpenzeel@gddeventer.com drying off quarters without DCT was not compensated by an increase in antibiotic use for treating CM. Total antibiotic use related to mastitis was reduced by $85 \%$ in these quarters.

Key words: selective dry cow therapy, intramammary infection, mastitis

\section{INTRODUCTION}

Mastitis is the consequence of IMI and occurs both in the dry and the lactating period of dairy cows (Barkema et al., 1998). New IMI may arise in the dry and the lactating period, possibly leading to clinical mastitis (CM) either directly after infection or later (Bradley and Green, 2000). The incidence of new IMI is highest during the dry period (Smith et al., 1985; Bradley and Green, 2004). To prevent the udder from acquiring new IMI during the dry period, the use of blanket dry cow therapy (DCT) has been advocated for almost $50 \mathrm{yr}$ as part of the 5-point mastitis management program (Neave et al., 1969). Intramammary infusion of longacting antibiotics at the end of lactation is an integral part of this program and was widely adopted in the Netherlands, with $87 \%$ of herds using blanket DCT and $11 \%$ using selective DCT in 2007 (Sampimon et al., 2008).

The goal of DCT is to reduce the prevalence of IMI, both by eliminating IMI already present at drying off and by preventing new IMI from occurring during the dry period (Bradley and Green, 2001). Antibiotic use, however, creates a selective pressure on bacterial populations and contributes to development of antimicrobial resistance (Tacconelli, 2009; Landers et al., 2012). Organizations, such as the World Health Organization, recommend reducing the use of antibiotics. In the dairy industry, prudent use of antibiotics comprises looking carefully at the use of blanket DCT, which includes preventive use of antibiotics in noninfected quarters.

In some countries, DCT is only applied for curative reasons, leading to a very low antibiotic use. Specifically, Nordic countries have used selective DCT as part of their national mastitis control program (Osterås and Sølverød, 2009). In the Netherlands, a study in the early 1990s showed that a decrease in DCT led 
to dramatic consequences, such as a 10 times higher incidence rate of clinical mastitis (IRCM) in quarters dried off without antibiotics (Schukken et al., 1993). In that study, however, a within-cow comparison on the effect of DCT was performed without separating uninfected and subclinically infected cows (Schukken et al., 1993).

Worldwide, cow-level SCC is used to identify cows that are likely subclinically infected with mastitis pathogens. Although this parameter is not perfect, the use of SCC to measure the inflammatory response to an IMI is a practical tool to evaluate udder health (Schukken et al., 2003). In the Netherlands, over the years, SCC selection thresholds for IMI were 150,000 cells $/ \mathrm{mL}$ for primiparous and 250,000 cells/mL for multiparous cows (de Haas et al., 2008; Windig et al., 2010).

The current study aimed to evaluate DCT in cows with low SCC (primiparous cows $<150,000$ cells $/ \mathrm{mL}$ and multiparous cows $<250,000$ cells $/ \mathrm{mL}$ ) at the last milk recording before drying off. The effect on CM, bacteriological status, SCC, and antibiotic use was evaluated when no DCT was administered in low-SCC cows. Additionally, the effect of bacteriological status and SCC at drying off on CM and SCC at 14 DIM was assessed.

\section{MATERIALS AND METHODS}

\section{Trial Design}

The effect of selective DCT was evaluated by no longer using antibiotics at drying off in low-SCC cows. Cows were classified as low-SCC cows when SCC at the last milk recording before drying off was $<150,000$ cells $/ \mathrm{mL}$ for primiparous and $<250,000$ cells $/ \mathrm{mL}$ for multiparous cows (de Haas et al., 2008), the thresholds used in the Dutch national milk recording. A split-udder design was used in which 2 lateral quarters of each cow were treated with antibiotics and the other 2 quarters remained as untreated controls, without antibiotics. The antibiotic treatment was randomly assigned to either the 2 right quarters or the 2 left quarters of each cow.

\section{Treatment}

Immediately after collection of the drying-off samples, the technician administered the treatment as outlined herein. The dry cow product contained 314 $\mathrm{mg}$ of potassium benzylpenicillin, $1,000 \mathrm{mg}$ of procaine benzylpenicillin, and $500 \mathrm{mg}$ of neomycin sulfate (Supermastidol, Virbac, Barneveld, the Netherlands). Technicians wore disposable gloves throughout the sanitization, sampling, and treatment process. After treatment, all 4 teats were disinfected with the disinfectant that was routinely used by the herdsman and the cow was marked as a dry cow. Herdsmen were blinded as to which quarters were treated with dry cow antibiotics.

\section{Sampling}

Milk samples were taken from each quarter at drying off (DRY) by the technician, within $12 \mathrm{~h}$ after calving (D0) by the herdsmen, and again at $14( \pm 7)$ DIM (D14) by the technician. Quarters with CM were identified and sampled by the herdsmen, all of whom had been trained in identification and sample collection. Milk samples collected by the technicians were stored at 3 to $8^{\circ} \mathrm{C}$ during shipment to the laboratory. All milk samples were collected aseptically by technicians and herdsmen after scrubbing teats using cotton-wool pledgets in $70 \%$ ethanol solution. Foremilk samples were collected according to IDF recommendations (IDF, 1981). Samples collected by the herdsmen were frozen at $-20^{\circ} \mathrm{C}$ at the farm and were taken to the laboratory for bacteriological analysis at the next visit by one of the technicians.

\section{Herds}

Herds were recruited throughout the Netherlands by advertisements in dairy magazines and agricultural websites. Farms participated on a voluntary base. Only conventional (nonorganic) farms with a minimum of 40 dairy cows who participated in the 4-, 5-, or 6-wk milk recording, including SCC measurement, were included. Ninety-nine herds were recruited, of which 2 dropped out, leaving 97 herds for analysis. One herd had a clinical outbreak of Klebsiella mastitis in an early stage of the study that was unrelated to the study. The herdsman of the other farm had underestimated the amount of labor associated with the study. The 97 herds were between 44 and 465 cows in size, with a median herd size of 94 cows.

\section{Animals}

Cows were eligible for recruitment to the study if they had no significant teat lesions, were in good health at the time of drying off (no clinical disease symptoms), and had 4 functional quarters. Herds were enrolled between June 2011 and March 2012. Cows were followed until October 2012. Herdspersons were not allowed to preselect animals. Every eligible cow within the study period was enrolled in the trial, with a maximum of 30 animals per herd, ensuring no bias was introduced from cow selection. A total of 1,680 animals were recruited from the 97 participating herds, of which 1,657 were available for analysis. Data of 657 primiparous cows 
(40\%) and 1,000 multiparous cows $(60 \%)$ were analyzed. Twenty-three animals did not finish the study due to early culling, death (not mastitis related), or missing data. The proportion of primiparous cows included in the study was relatively high compared with the age distribution of the herds (32\% primiparous cows in the herds). The total number of cows included per herd varied from 3 to 30 animals, with a median of 19 . The percentage of cows included per herd varied from 4 to $37 \%$, with a median of $17 \%$. All animals were followed from drying off to $100 \mathrm{~d}$ in lactation.

\section{Antibiotic Use}

Data on all individual antibiotic treatments were collected during the trial, comprising active compound, application route, dosage, frequency, and duration of treatment. Standardization of quantification of antibiotic use to compare animals presents difficulties due to differences in treatment regimens, dosages, metabolic differences within species, and a wide range in animal BW. Antibiotic use in this study was expressed as the number of animal daily dosages (ADD). One ADD is defined as a standardized 1-d treatment, being the average dose for a 1-d treatment of a registered veterinary drug for its main indication (Jensen et al., 2004). In this approach $1 \mathrm{ADD}$ is calculated as the dosage multiplied by the application frequency per day. Both, parenteral and intramammary treatment of an adult cow over 2 yr of age is expressed per $600 \mathrm{~kg}$, which is the defined standard BW. Antibiotic use for DCT was calculated as $1 \mathrm{ADD}$ per quarter treated with antibiotics at drying off, as defined by the standard operating procedure of the expert panel of the Netherlands Veterinary Medicines Authority. In our study, intramammary antibiotic treatments as well as parenteral antibiotic treatments related to mastitis were summed and allocated to the affected quarters. Total antibiotic use was calculated at the quarter level as antibiotics for DCT augmented with antibiotics used for intramammary and parenteral treatment of CM.

\section{Laboratory Analysis}

Somatic cell count was determined using SomaScope LFC 300 HP (Delta Instruments, Drachten, the Netherlands) according to the method of the International Dairy Federation (IDF, 1981). Bacteriological culturing was performed according to National Mastitis Council (NMC, 1999) recommendations. For routine samples $0.01 \mathrm{~mL}$ of milk was inoculated on $6 \%$ sheep blood agar and Streptococcus-selective Edward's agar (Biotrading, Mijdrecht, the Netherlands). A quarter was considered infected based on colony counts of the initial culture $\left(\geq 100 \mathrm{cfu} / \mathrm{mL}\right.$ ). Plates were incubated for $48 \mathrm{~h}$ at $37^{\circ} \mathrm{C}$ and examined after 24 and $48 \mathrm{~h}$ of incubation. Bacterial colonies were put on a template with a matrix. A matrix-assisted laser desorption/ionization time-offlight mass spectrometry (Bruker Daltonics, Bremen, Germany) was used for species identification allowing bacterial identification with high confidence and speed (Barreiro et al., 2010).

\section{Statistical Analysis}

Analysis was performed at the quarter level. In case a quarter was affected by $\mathrm{CM}$, this quarter was considered to be no longer at risk for CM; therefore, repeat cases of $\mathrm{CM}$ were not included in the analysis. To compare quarters dried off with or without antibiotics, IRCM was calculated for each group taking into account the number of quarter-days at risk in each group. Clinical mastitis, bacteriological status, and the percentage of quarters with a SCC above 200,000 cells/ $\mathrm{mL}$ (QSCC200) were compared between the groups using a chi-squared test. Mean SCC was compared using Kruskal-Wallis analysis.

The effect of SCC and bacteriological status for major pathogens at drying off on IRCM, as well as on the percentage of QSCC200 at D14, was analyzed using a multilevel logistic regression with 2 levels, adjusting for inclusion of multiple cows per herd and multiple quarters per cow. Data were analyzed using Stata12SE (Statacorp, College Station, TX). Results with $P<$ 0.05 were considered significant.

\section{Definitions}

A primiparous cow was defined as a first-lactation cow until the time she calved for the second time. A multiparous cow was defined as a cow that has calved at least twice. When a primiparous cow was dried off, this referred to drying off at the end of the first lactation. The CM that occurred during the dry period of primiparous cows was related to the dry period of animals before their second calving. Therefore, CM during the subsequent lactation of primiparous cows occurred in their second lactation.

A new IMI was defined as an IMI with a mastitis pathogen in a quarter at D0 or D14 if the quarter was culture-negative or culture-positive with another pathogen at drying off. Clinical mastitis occurred when visible changes in the milk or the quarter were observed, such as watery milk, clots or flakes, and changes and swelling or redness of the affected quarter. Clinical mastitis diagnosis was made by the herdsmen. Quarters were considered at risk from the date of drying off until 100 DIM in the following lactation, unless the quarter 
Table 1. Clinical mastitis $(\mathrm{n}=319)$ in quarters that did not $(\mathrm{NOAB})$ or did $(\mathrm{AB})$ receive dry cow antibiotics in low-SCC cows from 97 Dutch dairy herds ${ }^{1}$

\begin{tabular}{|c|c|c|c|c|}
\hline Item & $\operatorname{NOAB}(\mathrm{n}=200)$ & $\mathrm{AB}(\mathrm{n}=119)$ & Ratio & $P$-value \\
\hline Calving & $33(17)$ & $22(19)$ & 1.50 & 0.14 \\
\hline First 100 DIM & $130(65)$ & $87(73)$ & 1.49 & $<0.05$ \\
\hline
\end{tabular}

${ }^{1}$ Values are no. (\%) or median (25th-75th percentile).

${ }^{2}$ Incidence rate of clinical mastitis per quarter-day at risk.

was censored earlier because of $\mathrm{CM}$ or if the animal left the farm. An elevated SCC at the cow level was defined as an SCC $>150,000$ cells $/ \mathrm{mL}$ for primiparous and $>250,000$ cells $/ \mathrm{mL}$ for multiparous cows. An elevated SCC at the quarter level was defined as an SCC $>200,000$ cells/mL (QSCC200).

\section{RESULTS}

\section{CM}

In 86 out of 97 herds (89\%), 1 or more cases of CM were detected in the period from drying off to 100 DIM. A total of 319 quarter cases in 243 cows were observed, with 69 primiparous cows $(28 \%)$ and 174 multiparous cows (72\%). Of 243 cows, 182 had 1 affected quarter, 50 had 2 affected quarters, 7 had 3 affected quarters, and in 4 cows all 4 quarters were affected at some point during the study. The distribution of CM cases during different stages of lactation in quarters dried off with or without antibiotics is presented in Table 1. In the quarters dried off without antibiotics, 200 quarter cases of CM were observed, with 119 quarter cases of
CM in quarters dried off with antibiotics $(P<0.001)$. Across the whole study period, the IRCM in quarters dried off without antibiotics was 1.7 times $(95 \% \mathrm{CI}=$ 1.4-2.1) higher than in quarters dried off with antibiotics. The highest IRCM occurred during the first $21 \mathrm{~d}$ of lactation. The largest difference in IRCM, however, was found in the dry period, where quarters dried off without antibiotics had 3.7 times $(95 \% \mathrm{CI}=1.8-8.3)$ higher odds to acquire CM than quarters dried off with antibiotics. The distribution of pathogens for CM cases did not significantly differ between the quarters dried off with or without antibiotics. The predominant organism causing CM in both groups was Streptococcus uberis (Table 2).

An elevated quarter SCC at drying off was not associated with the occurrence of CM. Being culture-positive at the quarter level for major pathogens at drying off showed a trend for a higher risk of CM (Table 3).

\section{Bacteriological Status}

Data on the bacteriological status of all quarters in the study at DRY, D0, and D14 are presented in Table

Table 2. Bacteriological results (no., with percentage in parentheses) from clinical mastitis $(\mathrm{n}=319)$ in quarters that did not $(\mathrm{NOAB})$ or did $(\mathrm{AB})$ receive dry cow antibiotics in low-SCC cows from 97 Dutch dairy herds

\begin{tabular}{|c|c|c|c|}
\hline Item & $\begin{array}{c}\text { NOAB } \\
(\mathrm{n}=200)^{1}\end{array}$ & $\begin{array}{c}\mathrm{AB} \\
(\mathrm{n}=119)^{1}\end{array}$ & $P$-value \\
\hline Culture negative & $50(25)$ & $32(27)$ & 0.30 \\
\hline Other bacteria $^{2}$ & $7(4)$ & $7(6)$ & 0.13 \\
\hline Contaminated & $6(3)$ & $3(3)$ & 0.94 \\
\hline No sample & $37(19)$ & $34(29)$ & \\
\hline Major pathogen & $83(42)$ & $36(30)$ & 0.17 \\
\hline Minor pathogen & $18(9)$ & $8(7)$ & 0.67 \\
\hline \multicolumn{4}{|c|}{ Major pathogen ( $\mathrm{n}=83$ and 36 for NOAB and $\mathrm{AB}$, respectively) } \\
\hline Staphylococcus aureus & $24(12)$ & $7(6)$ & 0.13 \\
\hline Escherichia coli & $14(7)$ & $6(5)$ & 0.66 \\
\hline Klebsiella spp. & 0 & $1(1)$ & 0.17 \\
\hline Streptococcus uberis & $31(16)$ & $12(10)$ & 0.31 \\
\hline Streptococcus dysgalactiae & $7(4)$ & $7(6)$ & 0.21 \\
\hline Trueperella pyogenes & $10(5)$ & $6(5)$ & 0.80 \\
\hline \multicolumn{4}{|c|}{ Minor pathogen ( $\mathrm{n}=18$ and 8 for NOAB and $\mathrm{AB}$, respectively) } \\
\hline CNS & $12(6)$ & $8(7)$ & 0.59 \\
\hline Corynebacterium spp. & $6(3)$ & 0 & 0.07 \\
\hline
\end{tabular}

${ }^{1}$ Samples could be culture positive for more than one pathogen.

${ }^{2}$ Other bacteria, such as Proteus spp., Bacillus spp., Enterococcus spp. 
Table 3. Results of the multilevel, multivariable model for the association between SCC and culture positive for major mastitis pathogens at drying off (DRY) and the occurrence of clinical mastitis (CM) and the percentage of quarters with SCC $>200,000$ cells $/ \mathrm{mL}(\mathrm{QSCC} 200)$ at $\mathrm{d} 14^{1}$

\begin{tabular}{lll}
\hline Item & $\begin{array}{c}\text { CM, } \\
\mathrm{OR}^{2}(95 \% \mathrm{CI})\end{array}$ & $\begin{array}{c}\text { QSCC200 (d 14), } \\
\text { OR (95\% CI) }\end{array}$ \\
\hline QSCC200 (DRY) & $1.3(0.96 ; 1.8)$ & $1.5(1.2 ; 1.8)$ \\
Culture positive for major mastitis pathogen (DRY) & $1.8(0.89 ; 3.7)$ & $1.6(0.95 ; 2.6)$ \\
Untreated & $2.0(1.5 ; 2.5)$ & $2.0(1.7 ; 2.3)$ \\
\hline
\end{tabular}

${ }^{1}$ Model adjusted for multiple cows per herd and multiple quarters per cow.

${ }^{2} \mathrm{OR}=$ odds ratio.

4. No significant difference was found between the groups of treated and untreated quarters in bacteriological status at DRY. Of all quarters, $65 \%$ were culture negative, approximately $24 \%$ of samples were positive for minor pathogens (CNS and Corynebacterium spp.), and approximately $2.4 \%$ for major pathogens.

At D0, significantly more samples were culturenegative in quarters dried off with antibiotics (62\%) as compared with quarters dried off without antibiotics $(51 \%)$. Significantly fewer samples were culturepositive for major pathogens (4.3 vs. $9.3 \%$ ) and minor pathogens $(12.2$ vs. $18.2 \%)$ in quarters dried off with antibiotics as compared with quarters dried off without antibiotics (Table 4). Although prevalence of culturepositive samples had slightly decreased at D14, comparable differences were found for major pathogens (3.4 vs. $6.2 \%$ ) as well as minor pathogens (12.2 and $22.1 \%$ ) in quarters dried off with antibiotics as compared with quarters dried off without antibiotics. The largest differences were found for Escherichia coli, Strep. uberis, and Corynebacterium spp. (Table 4).

\section{SCC}

The percentage of quarters with a QSCC200 at DRY, despite a low cow SCC, was $36 \%$. The mean SCC at drying off did not significantly differ between quarters dried off with or without antibiotics. Similarly, the groups did not significantly differ in the percentage of QSCC200 at drying off. At D0 and D14, SCC was significantly higher in quarters that were not dried off with antibiotics (Table 5).

Quarters with an elevated SCC at DRY had a higher risk for an SCC above 200,000 cells/mL at D14. Similarly, quarters with a positive culture for major pathogens at DRY had a higher risk for an SCC above 200,000 cells/mL at D14. The last effect was confounded by the risk of an elevated SCC in the multivariable model (Table 3).

\section{Antibiotic Use}

In quarters dried off with antibiotics 3,314 ADD were used for DCT. For treatment of first cases of CM during the dry period and the first $100 \mathrm{~d}$ after calving in these quarters, 265 intramammary treatments with 12-h treatment intervals and 107 intramammary treatments with 24-h treatment intervals were used, resulting in 239.5 intramammary ADD. Additionally, for parenteral treatment of CM in quarters dried off with antibiotics, 138.5 ADD were used. This resulted in a total of 3,692 ADD (Table 6).

In quarters dried off without antibiotics, obviously no ADD were used for DCT. For treatment of first cases of CM during the dry period and the first $100 \mathrm{~d}$ after calving in these quarters, 366 intramammary treatments with 12-h treatment intervals and 110 intramammary treatments with 24-h treatment intervals were used, resulting in 293 intramammary ADD. Additionally, for parenteral treatment of CM in quarters dried off without antibiotics, 248.5 ADD were used. This resulted in a total of 541.5 ADD (Table 6). In quarters dried off without antibiotics, total antibiotic use is $85 \%$ [100\% $(541.5 / 3,692) \times 100 \%]$ lower than in quarters dried off with antibiotics.

\section{DISCUSSION}

The IRCM during the dry period and the first $100 \mathrm{~d}$ of lactation of quarters dried off without antibiotics was significantly higher than in quarters treated with dry cow antibiotics. The high IRCM found during the dry period may have been influenced by herdsmen paying specific attention to the udders of participating cows during the dry period. Because herdsmen were not aware of which quarters received dry cow antibiotics, this potential bias was similar for quarters dried off with or without antibiotics.

In the current study, the IRCM in quarters dried off without antibiotics was 1.7 times higher than in quarters dried off with antibiotics. Previous work found similar results. Hassan et al. (1999) found 1.4 times more CM in quarters dried off without antibiotics and Schukken et al. (1993) reported 2 times more new IMI with major and minor pathogens in quarters dried off without antibiotics in a herd with a low bulk tank SCC. Given that in these studies, cows were not selected based on 
Table 4. Prevalence of pathogens in all quarters that did not (NOAB) or did (AB) receive dry cow antibiotics at drying off (DRY), at calving (D0), and at 14 DIM (D14) in low-SCC cows from 97 Dutch dairy herds

\begin{tabular}{|c|c|c|c|c|c|c|c|c|c|c|c|c|}
\hline \multirow[b]{3}{*}{ Item } & \multicolumn{4}{|c|}{ DRY } & \multicolumn{4}{|c|}{ D0 } & \multicolumn{4}{|c|}{ D14 } \\
\hline & \multicolumn{2}{|c|}{$\begin{array}{c}\text { NOAB } \\
(\mathrm{n}=3,314)^{1}\end{array}$} & \multicolumn{2}{|c|}{$\begin{array}{c}\mathrm{AB} \\
(\mathrm{n}=3,314)^{1}\end{array}$} & \multicolumn{2}{|c|}{$\begin{array}{c}\text { NOAB } \\
(\mathrm{n}=3,314)^{1}\end{array}$} & \multicolumn{2}{|c|}{$\begin{array}{c}\mathrm{AB} \\
(\mathrm{n}=3,314)^{1}\end{array}$} & \multicolumn{2}{|c|}{$\begin{array}{c}\text { NOAB } \\
(\mathrm{n}=3,314)^{1}\end{array}$} & \multicolumn{2}{|c|}{$\begin{array}{c}\mathrm{AB} \\
(\mathrm{n}=3,314)^{1}\end{array}$} \\
\hline & no. & $\%$ & no. & $\%$ & no. & $\%$ & no. & $\%$ & no. & $\%$ & no. & $\%$ \\
\hline Culture negative & 2,171 & 66 & 2,155 & 65 & $1,693^{* *}$ & 51 & $2,039^{* *}$ & 62 & $1,958^{* *}$ & 59 & $2,380^{* *}$ & 72 \\
\hline Other bacteria $^{2}$ & 157 & 4.7 & 142 & 4.3 & 186 & 5.6 & 189 & 5.7 & 135 & 4.1 & 146 & 4.4 \\
\hline Contaminated & 132 & 4 & 137 & 4.1 & 278 & 8.4 & 275 & 8.3 & 149 & 4.5 & 126 & 3.8 \\
\hline No sample & 0 & & 0 & & 286 & 8.6 & 281 & 8.5 & 170 & 5.1 & 156 & 4.7 \\
\hline Major pathogen & 71 & 2.1 & 86 & 2.6 & 307 & 9.3 & 141 & 4.3 & 206 & 6.2 & 113 & 3.4 \\
\hline Minor pathogen & 793 & 24 & 807 & 24 & 603 & 18 & 405 & 12 & 732 & 22 & 405 & 12 \\
\hline \multicolumn{13}{|l|}{ Major pathogen ${ }^{3}$} \\
\hline Staphylococcus aureus & 18 & 0.5 & 12 & 0.4 & $62^{* *}$ & 1.9 & $36^{* *}$ & 1.1 & $56^{* *}$ & 1.7 & $32^{* *}$ & 1.0 \\
\hline Escherichia coli & 4 & 0.1 & 2 & 0.1 & $33^{* *}$ & 1.0 & $14^{* *}$ & 0.4 & $21^{* *}$ & 0.6 & $4^{* *}$ & 0.1 \\
\hline Klebsiella spp. & 0 & & 0 & & 3 & 0.1 & 1 & 0.0 & 2 & 0.1 & 2 & 0.1 \\
\hline Streptococcus agalactiae & 0 & & 0 & & 0 & & 1 & 0.0 & 0 & & 0 & \\
\hline Streptococcus uberis & 13 & 0.4 & 21 & 0.6 & $94^{* *}$ & 2.8 & $32^{* *}$ & 1.0 & $53^{* *}$ & 1.6 & $20^{* *}$ & 0.6 \\
\hline Streptococcus dysgalactiae & 7 & 0.2 & 11 & 0.3 & $44^{*}$ & 1.3 & $23^{*}$ & 0.7 & 14 & 0.4 & 8 & 0.2 \\
\hline Serratia marcescens & 0 & & 0 & & 3 & 0.1 & 0 & & 4 & 0.1 & 0 & \\
\hline Trueperella pyogenes & 1 & 0.0 & 0 & & 16 & 0.5 & 10 & 0.3 & 6 & 0.2 & 11 & 0.3 \\
\hline Alpha-hemolytic streptococci & 28 & 0.8 & 40 & 1.2 & $52^{*}$ & 1.6 & $24^{*}$ & 0.7 & 50 & 1.5 & 36 & 1.1 \\
\hline \multicolumn{13}{|l|}{ Minor pathogen ${ }^{4}$} \\
\hline CNS & 283 & 8.5 & 277 & 8.4 & 416 & 13 & 357 & 11 & 295 & 8.9 & 286 & 8.6 \\
\hline Corynebacterium spp. & 510 & 15 & 530 & 16 & $187^{* *}$ & 5.6 & $48^{* *}$ & 1.4 & $437^{* *}$ & 13 & $119^{* *}$ & 3.6 \\
\hline
\end{tabular}

¿ $\quad{ }^{1}$ Samples could be positive for more than one pathogen.

20ther bacteria such as Proteus spp., Bacillus spp., Enterococcus spp.

@ $\quad{ }^{3}$ Major pathogens were found in 71, 86, 307, 141, 206, and 113 quarters of NOAB (DRY), AB (DRY), NOAB (d 0), AB (d 0), NOAB (d 14), and AB (d 14), respectively.

$\rightarrow{ }^{4}$ Minor pathogens were found in 793, 807, 603, 405, 732, and 405 quarters of NOAB (DRY), AB (DRY), NOAB (d 0), AB (d 0), NOAB (d 14), and AB (d 14), respectively.

兰. *Quarters dried off without antibiotics differed significantly $(P<0.05)$ from quarters dried off with antibiotics.

**uarters dried off without antibiotics differed significantly $(P<0.01)$ from quarters dried off with antibiotics. 
Table 5. Quarter SCC and number of quarters with SCC $>200,000$ cells/mL (QSCC200) in quarters $(\mathrm{n}=6,628)$ that did not $(\mathrm{NOAB})$ or did $(\mathrm{AB})$ receive dry cow antibiotics in low-SCC cows from 97 Dutch dairy herds

\begin{tabular}{|c|c|c|c|c|c|c|c|}
\hline Item & \multicolumn{3}{|c|}{ NOAB } & \multicolumn{3}{|c|}{$\mathrm{AB}$} & $P$-value \\
\hline At drying off & 3,314 & $121(46-310)$ & & 3,314 & $120(47-315)$ & & 0.77 \\
\hline At calving & 1,450 & $772(225-2,035)$ & & 1,472 & $578(180-1,380)$ & & $<0.01$ \\
\hline 14 DIM & 3,100 & $46(18-143)$ & & 3,103 & $30(13-76)$ & & $<0.01$ \\
\hline 14 DIM & 3,100 & & $610(20)$ & 3,103 & & $388(13)$ & $<0.01$ \\
\hline
\end{tabular}

${ }^{1} \mathrm{p} 25-\mathrm{p} 75=25$ th- 75 th percentile.

SCC as they were in our study, the relative risk of no dry cow treatment in our study was fairly large.

The highest IRCM in our study was found during the dry period and the first $21 \mathrm{~d}$ of lactation, with Strep. uberis as the predominant organism causing CM. This is similar to previous reports on the incidence of new IMI and prevalence of Strep. uberis in the dry period (Woolford et al., 1998; Berry and Hillerton, 2002). Up to $50 \%$ of enterobacterial CM cases that occur within the first 100 DIM arise in quarters that were already infected during the dry period (Bradley and Green, 2000). This suggests that antimicrobial DCT did not actually work as effectively as depicted. It also shows a relationship between IMI present during the dry period and CM cases occurring after calving seems to exist. Although dry cow antibiotics are no longer active during lactation, a significant effect on IRCM still occurs during the first 100 DIM.

When comparing the effect of severity of CM cases in both groups, quarters dried off with and without antibiotics show equal percentages of mild and severe cases (data not shown). This judgment of severity was based on whether or not parenteral treatment was administered to treat the $\mathrm{CM}$ case. Additionally, ADD per CM cases were similar in both groups of quarters. Thus, severity of CM did not seem to be influenced by the use of dry cow antibiotics.

When evaluating the preventive effect of DCT, Halasa et al. (2009) found that quarter-level selection for drying off with antibiotics protected significantly better against new IMI during the dry period up to 21 d postcalving compared with quarters dried off without antibiotics. In a meta-analysis of 5 studies, blanket DCT was compared with selective DCT and showed no significant difference in protection against new IMI in 3 studies when cow-level selection was practiced for drying off with antibiotics. This indicates no preventive effect of DCT in this approach (Rindsig et al., 1978; Browning et al., 1994; Williamson et al., 1995). However, these studies are hard to compare with our study because they were carried out over $20 \mathrm{yr}$ ago in herds with different housing systems and with different production levels. In spite of the differences in results between these studies, the overall conclusion is that blanket DCT has a protective effect against new IMI as compared with selective DCT, which is in line with our findings.

In the current study, variation in the treatment groups due to herd or cow factors was minimal because of the split-udder design. The benefit of a split-udder design is that cow- and herd-level factors are the same for both groups of quarters and cannot influence the results. Both groups of quarters have the same genetic background, eat the same ration, are milked by the same milking machine, experience the same infection pressure, and so on. A disadvantage of the split-udder design is that quarters dried off with or without antibiotics may influence each other, possibly leading to

Table 6. Antibiotic use at quarter level related to dry cow and clinical mastitis treatment expressed as animal daily dosages (ADD) in low-SCC cows from 97 Dutch dairy herds

\begin{tabular}{lcc}
\hline Item & $\begin{array}{c}\text { ADD quarters dried } \\
\text { off with antibiotics } \\
(\mathrm{n}=3,314)\end{array}$ & $\begin{array}{c}\text { ADD quarters dried } \\
\text { off without antibiotics } \\
(\mathrm{n}=3,314)\end{array}$ \\
\hline Dry cow therapy & $3,314.0$ & 0.0 \\
Intramammary mastitis treatment $_{\text {Parenteral mastitis treatment }}{ }^{1}$ & 239.5 & 293.0 \\
Total ADD & 138.5 & 248.5 \\
${ }^{1}$ Parenteral mastitis treatment was calculated based on clinical mastitis cases occurring in the specific quarters.
\end{tabular}


an underestimation of effect (Lam et al., 1996). Due to the advantages mentioned, however, a within-cow comparison is often used as an approach in these types of studies (Schukken et al., 1993; Bradley et al., 2010).

For differences between herds we used multilevel models adjusted for random herd effects. Herds may differ in their pathogen prevalence and environmental management, thus dry cow treatment effects can be very different between herds (Halasa et al., 2009; Rajala-Schultz et al., 2011). For that reason the number of cows per herd was maximized, forcing us to include a high number of herds in the study. Nevertheless optimal dry cow antibiotic application may vary from herd to herd.

Somatic cell count and QSCC200 at D0 and D14 were significantly higher in quarters dried off without antibiotics. An elevated SCC or being culture-positive for major pathogens at DRY were associated with a higher QSCC200 at D14. Being culture-positive for major pathogens at DRY was neither significantly associated with CM during the period of study nor with QSCC200 at D14. This is possibly due to the low numbers of samples positive for major pathogens at DRY (2.4\%). The limited statistical power may also explain why an SCC above 200,000 cells/mL at quarter level at DRY was neither associated with CM during the dry period, nor with QSCC200 at D14 in the multivariable model.

In daily practice, different criteria can be used to select cows for DCT or no DCT. Decision-making can be done on the herd level (e.g., bulk tank milk SCC), cow level (e.g., SCC, CM history, parity), or quarter level (e.g., SCC, teat end condition). In our study, we chose to select primiparous cows with an $\mathrm{SCC}<150,000$ cells/mL and multiparous cows with an $\mathrm{SCC}<250,000$ cells $/ \mathrm{mL}$ on the last milk recording before drying off because of the practical implementation in daily practice when using milk recording data. We chose SCC at the quarter level as a dependent variable for obvious reasons, with 200,000 cells $/ \mathrm{mL}$ as a threshold. This was chosen to minimize diagnostic error, as described by Schukken et al. (2003).

Despite more antibiotic use for treatment of CM, total antibiotic use related to mastitis was substantially reduced, $85 \%$ based on calculated ADD at the quarter level, in quarters dried off without antibiotics. Calculating a DCT injector as 1 ADD underestimates the possible effect of antibiotic use, because the real activity of the antimicrobial compound in DCT lasts longer than $1 \mathrm{~d}$. Using another unit for antibiotic use due to DCT would have increased the difference in antibiotic use between quarters dried off with or without antibiotics even further.

Although selective DCT leads to more cases of CM and higher SCC in low-SCC cows, the reduction in an- tibiotic use is substantial. The effects on mastitis and antibiotic use, which are parameters of different magnitude, have to be weighted when deciding on applying blanket or selective DCT. To judge the importance of reduction of antibiotic use, the effect on antibiotic resistance has to be estimated, which was not part of the current study. Future studies should focus on whether a reduction of the use of dry cow antibiotics has an effect on selective pressure and thus on the risk on development of antimicrobial resistance. In conclusion, selection of animals for therapy with dry cow antibiotics based on their SCC at the last milk recording before drying off gives a substantial reduction in antibiotic use, but leads to an increase in CM, subclinical mastitis, and culture-positive quarters.

\section{ACKNOWLEDGMENTS}

This study was financially supported by the Dutch Dairy Board (PZ, Zoetermeer, the Netherlands). The authors gratefully acknowledge the efforts of Otlis Sampimon (Zoetis, Capelle a/d IJssel, the Netherlands) for his contribution to the study design. The authors appreciate the cooperation of the dairy producers and technicians involved in this study.

\section{REFERENCES}

Barkema, H. W., Y. H. Schukken, T. J. G. M. Lam, M. L. Beiboer, H. Wilmink, G. Benedictus, and A. Brand. 1998. Incidence of clinical mastitis in dairy herds grouped in three categories by bulk milk somatic cell counts. J. Dairy Sci. 81:411-419.

Barreiro, J. R., C. R. Ferreira, G. B. Sanvido, M. Kostrzewa, T. Maier, B. Wegemann, V. Bottcher, M. N. Eberlin, and M. V. dos Santos. 2010. Short communication: Identification of subclinical cow mastitis pathogens in milk by matrix-assisted laser desorption/ionization time-of-flight mass spectrometry. J. Dairy Sci. 93:5661-5667.

Berry, E. A., and J. E. Hillerton. 2002. The effect of selective dry cow treatment on new intramammary infections. J. Dairy Sci. $85: 112-121$.

Bradley, A. J., J. E. Breen, B. Payne, P. Williams, and M. J. Green. 2010. The use of a cephalonium containing dry cow therapy and an internal teat sealant, both alone and in combination. J. Dairy Sci. 93:1566-1577.

Bradley, A. J., and M. J. Green. 2000. A study of the incidence and significance of intramammary enterobacterial infections acquired during the dry period. J. Dairy Sci. 83:1957-1965.

Bradley, A. J., and M. J. Green. 2001. An investigation of the impact of intramammary antibiotic dry cow therapy on clinical coliform mastitis. J. Dairy Sci. 84:1632-1639.

Bradley, A. J., and M. J. Green. 2004. The importance of the nonlactating period in the epidemiology of intramammary infection and strategies for prevention. Vet. Clin. North Am. Food Anim. Pract. 20:547-568.

Browning, J. W., G. A. Mein, P. Brightling, T. J. Nicholls, and M. Barton. 1994. Strategies for mastitis control: Dry cow therapy and culling. Aust. Vet. J. 71:179-181.

de Haas, Y., W. Ouweltjes, J. ten Napel, J. J. Windig, and G. de Jong. 2008. Alternative somatic cell count traits as mastitis indicators for genetic selection. J. Dairy Sci. 91:2501-2511.

Halasa, T., M. Nielen, A. C. Whist, and O. Osteras. 2009. Metaanalysis of dry cow management for dairy cattle. Part 2. Cure of existing intramammary infections. J. Dairy Sci. 92:3150-3157. 
Hassan, Z., R. C. Daniel, D. O'Boyle, and A. J. Frost. 1999. Effects of dry cow intramammary therapy on quarter infections in the dry period. Vet. Rec. 145:635-639.

IDF (International Dairy Federation). 1981. Laboratory Methods for Use in Mastitis Work. IDF Bull. 132. Int. Dairy Fed., Brussels, Belgium.

Jensen, V. F., E. Jacobsen, and F. Bager. 2004. Veterinary antimicrobial-usage statistics based on standardized measures of dosage. Prev. Vet. Med. 64:201-215.

Lam, T. J. G. M., M. C. de Jong, Y. H. Schukken, and A. Brand. 1996. Mathematical modeling to estimate efficacy of postmilking teat disinfection in split-udder trials of dairy cows. J. Dairy Sci. $79: 62-70$

Landers, T. F., B. Cohen, T. E. Wittum, and E. L. Larson. 2012. A review of antibiotic use in food animals: Perspective, policy, and potential. Public Health Rep. 127:4-22.

Neave, F. K., F. H. Dodd, R. G. Kingwill, and D. R. Westgarth. 1969 Control of mastitis in the dairy herd by hygiene and management. J. Dairy Sci. 52:696-707.

NMC (National Mastitis Council). 1999. Laboratory Handbook on Bovine Mastitis. Natl. Mastitis Counc. Inc., Madison, WI.

Osterås, O., and L. Sølverød. 2009. Norwegian mastitis control programme. Ir. Vet. J. 62(Suppl. 4):S26-S33.

Rajala-Schultz, P. J., A. H. Torres, and F. J. Degraves. 2011. Milk yield and somatic cell count during the following lactation after selective treatment of cows at dry-off. J. Dairy Res. 78:489-499.

Rindsig, R. B., R. G. Rodewald, A. R. Smith, and S. L. Spahr. 1978 Complete versus selective dry cow therapy for mastitis control. J. Dairy Sci. 61:1483-1497.
Sampimon, O. C., R. G. M. Olde Riekerink, and T. J. G. M. Lam. 2008. Prevalence of subclinical mastitis pathogens and adoption of udder health management practices on Dutch dairy farms: Preliminary results. Pages 39-46 in Proceedings of Mastitis Control: From Science to Practice 2008, The Hague, the Netherlands. Wageningen Academic Publishers, Wageningen, the Netherlands.

Schukken, Y. H., J. Vanvliet, D. Vandegeer, and F. J. Grommers 1993. A randomized blind trial on dry cow antibiotic infusion in a low somatic cell count herd. J. Dairy Sci. 76:2925-2930.

Schukken, Y. H., D. J. Wilson, F. Welcome, L. Garrison-Tikofsky, and R. N. Gonzalez. 2003. Monitoring udder health and milk quality using somatic cell counts. Vet. Res. 34:579-596.

Smith, K. L., D. A. Todhunter, and P. S. Schoenberger. 1985. Environmental pathogens and intramammary infection during the dry period. J. Dairy Sci. 68:402-417.

Tacconelli, E. 2009. Antimicrobial use: Risk driver of multidrug resistant microorganisms in healthcare settings. Curr. Opin. Infect. Dis. 22:352-358.

Williamson, J. H., M. W. Woolford, and A. M. Day. 1995. The prophylactic effect of a dry-cow antibiotic against Streptococcus uberis N. Z. Vet. J. 43:228-234.

Windig, J. J., W. Ouweltjes, J. Ten Napel, G. de Jong, R. F. Veerkamp, and Y. De Haas. 2010. Combining somatic cell count traits for optimal selection against mastitis. J. Dairy Sci. 93:1690-1701.

Woolford, M. W., J. H. Williamson, A. M. Day, and P. J. Copeman. 1998. The prophylactic effect of a teat sealer on bovine mastitis during the dry period and the following lactation. N. Z. Vet. J. 46:12-19. 